\title{
RURAL NARRATIVES ON TRAVEL AND SAFETY: IMPLICATIONS FOR COMMUNITY DEVELOPMENT IN RURAL COMMUNITIES IN SOUTHEAST NIGERIA
}

\author{
MATTHIAS U. AGBOEZE ${ }^{1}$, ELOCHUKWU A. NWANKWO ${ }^{2 *} \&$ DORIDA N. OYIGBO ${ }^{3}$ \\ ${ }^{1,3}$ Department of Adult Education and Extramural Studies, University of Nigeria, Nsukka \\ ${ }^{2}$ Department of Archaeology and Tourism, University of Nigeria, Nsukka
}

\begin{abstract}
The study was aimed at understanding the safety narratives on travel among rural adults and, the implications of this for community development in rural Nigeria. Key Informant Interview and Focus Group Discussion (FGD) approaches were adopted. Cluster, purposive and convenience sampling techniques aided the sampling of fifty rural adults, ten tourism development experts and ten community development experts from selected communities in Southeast Nigeria. Moreover, Yaro Yamene Fomular aided in downsizing the huge study population to a sample size of 354 respondents who were shared questionnaires. Mean and standard deviation were used to answer the research questions while analysis of variance was used to test the null hypotheses at 0.05 level of significance. The result shows that rural adults perceive huge safety threats in travels and this indirectly affects community development in rural Nigeria. Also, that travel motivates rural development through necessary exposures, new ideologies, critical criticisms, and trending community development approaches. This study has implications for exploring travel as an alternative route to community development in rural areas.
\end{abstract}

KEYWORDS: Travel; Safety; Rural Adults; Community Development; Rural Communities \& Sustainable Development

Received: Jun 15 2021; Accepted: Jul 05, 2021; Published: Jul 16, 2021; Paper Id.: IJMPERDAUG202123

\section{INTRODUCTION}

People take both short and long distance travels for different purposes ranging from personal, family and/or group intentions. Although this could either be domestic or international travel, but domestic travel take over $75 \%$ of total travel in Nigeria with land transportation (vehicles) occupying over $65 \%$ of this percentage. Domestic travel in Nigeria is largely facilitated by commercial road transport companies and other private cars (Udensi, Udoh, Daasi \& Igbara 2012; Oruonye 2013; Adedeji, Olofiaji, Omole, Olanibe, \& Yusuf 2014; Ononogbo 2014). The government has been able to facilitate this as well through the provision of different classes of road networks for travels across the federation of Nigeria. While some of these roads are relatively old some are newly constructed and with some levels of maintenance on the old ones to facilitate road travels in Nigeria.

Many rural communities abound in Nigeria which outnumber the few densely populated semi-urban and urban areas. Many studies have noted that most of the rural communities in Nigeria are left to wallow in abject poverty, neglected and abandoned with limited or no economically motivated initiatives (Olayiwola \& Adeleye 2005; Musa 2010; Nduchuwe \& Adejuwon 2012; Ocheni, Atakpa \& Nwankwo 2012; Saliu 2014). This does not only contribute to the avoidable huge rural-urban migration in search of better economic opportunities but also cause huge loss on the economies of the few urban and semi-urban areas through population explosion with 
resultant increase in the decay of the existing infrastructures and rise in social vices. Also, the constant migrations to the urban areas have left most of the rural communities impoverished with limited infrastructural and economic motivation. For information, one of the major motivations for those living in rural areas is kinship ties and communal existence. That notwithstanding, the incessant migration to urban areas greatly affected the rural population distribution with a greater percentage $(65 \%)$ of the population occupied by adults over 50 years of age.

This ugly scenario has placed the rural population in a poor economic state. Efforts are being made towards the revamping of the economy of these rural areas in Nigeria to make the people to be reasonably comfortable and reduce rural-urban migration significantly. Some previous studies have proposed some possible solutions to that effect. These include Self-need projects, infrastructural provisions, adult literacy programs, MDG and SDG projects, etc (McGregor and Thompson-Faweett 2004; Olayiwola \& Adeleye 2005; Musa 2010; Ivolga \& Erokhin 2013; Chin, Lo, Songan \& Nair 2014; Agboeze \& Nwankwo 2016; Petrovic, Vujko, Gajic, Vukovic, Radovanovic, Jovanovic \& Vukovic 2018). Recently, travels were suggested as part of the escape routes to the poor economic state of the rural areas. Some studies have argued that travels bring exposures, new ideologies, enlightenment, and awareness among others that have the tendencies of transforming the economic fortunes of rural communities (Kostynivk, Louis, Zanier, Eby \& Molner 2012; Beck, Downs, Stevens, \& Sauber-Schatz 2017; Cerin, Nathan, Van Cauwenberg, Barnett \& Barnett 2017). Rural adults in Nigeria stand a chance of making a significant impact on their standard of living in the rural communities through various domestic and international travels.

However, it is quite unfortunate that most of the rural adults are not motivated to travel no matter the distance (local, national and international). Many of them could stay for as long as 365 days without making any significant travel outside their communities. What may have caused this attitude to travel among rural adults? There are critical factors that could determine the extent of travel and /or decision to travel among rural adults. These include available disposable income, leisure, opportunities, time/distance, and safety (Dolnicar, 2005; Jones, Tedla, Zephniah, Appiah-Opoku, Tefe \& Walsh 2014; Hasan, Ishamail \& Islam 2017). Safety considerations could be more critical among these factors. How have rural adults perceived safety as motivation to travel and what is the implication of this perception for sustainable development of rural communities in Southeast Nigeria? In this regard, this study tends to find out the perception of safety and travel among rural adults and the implications for sustainable development of rural communities in Nigeria with a focus on rural areas in Southeast Nigeria. The study has implications for the revitalization of the contributions of travel to the revamping of rural economies in Nigeria.

\section{METHOD}

The principle of triangulation as proposed by Dzurec and Abraham (1993), was adopted for the study. This principle implies approaching a study through different methods to get a more verifiable and reliable result. In this case, Key Informant Interview and Focus Group Discussion (FGD) approaches were adopted from the qualitative method. Cluster, purposive and convenience sampling techniques aided the sampling of fifty rural adults, ten tourism development experts and ten community development experts from selected communities in Southeast Nigeria, to ascertain the perception of safety and travel, and the implications for sustainable development of rural communities. Ten different FGD sessions were organized from ten different rural communities among the five states in Southeast Nigeria. Data from these qualitative approaches were analyzed using the descriptive method 
Moreover, on the quantitative method, YaroYamene Fomular aided in downsizing the huge study population to a sample size of 236 rural adults, 59 tourism development experts, and 59 community development experts. 354 structured questionnaires were distributed among these respondents from the study area of Southeast Nigeria. However, data collected were analysed using mean, standard deviation and analysis of variance. Mean and standard deviation were used to answer the research questions while Analysis of Variance was used to test the null hypotheses at 0.05 level of significance. A criterion mean of 2.50 was used for decision rule. Thus, any item that had a mean of 2.50 and above was regard as 'Agree' while the one that had mean less than 2.50 was regarded as 'Disagree'. A null hypothesis was not rejected if the associated probability value was greater than 0.05 level of significance, otherwise the null hypothesis was rejected. However, the authors wish to state that this manuscript complied with the stipulated ethical guidelines for such studies and has full approval of the University of Nigeria Ethical Committee.

\section{CLARIFICATION OF KEY CONCEPTS}

Clarification of some of the basic concepts used in this study will facilitate the understanding of the basic premise of the study. To this regard, rural adult as applied in this study has to do with that segment of the rural population that is classified as adults. They range from 30 to 100 years of age with the remaining 71-100 classified as the age range among rural adults. The emphasis of this study is on the active rural adult (30-70 years). This comprises men and women who are predominantly farmers, traditional industrialists, retirees and petty traders

On the other hand, travel has to do with movement from one place to another with specific reasons irrespective of the distance and cost. Such travels could be local, regional, national or international (McAndrews, Beyer, Guse \& Layde 2016). Emphasis of this study is on those categories of movements that involve rural adults outside their traditional communities with greater emphasis on domestic travels. Safety on the other hand has to do with the state of being safe from threats, hazards and other misfortunes (Jones, Tedla, Zephniah, Appiah-Opoku, Tefe \& Walsh 2014). In this study, safety is seen as the state of the feeling of being safe with respect to travels among rural adults outside their localities.

Sustainable development of rural communities has to do with a systematic kind of development that is designed for rural communities to serve their felt-needs for today and tomorrow. Such developments are targeted at long term impact on rural dwellers with collection acceptance from members of the rural community (Koscak, 1998; Ocheni et al 2012; Udensi et al 2012; Ivolga \& Erokhin 2013; Uzobo \& Dawodu 2015; Ibanescu et al 2018). In this study sustainable development of rural communities has to do with efforts, programmes such as adult education programmes and/or activities like travel, with a view to improving the living standard of the rural dwellers through provision of alternative sources of income, new ideologies, enlightenments and motivations for felt-need projects.

Finally, Southeast Nigeria is the focus of the study. This is one of the six geopolitical regions in Nigeria with predominant population of Igbos. The region has five states: Anambra, Enugu, Imo, Abia and Ebonyi states (see Figure 1 below). Over four hundred rural communities abound in these states with few urban and semi-urban areas. This study is focused on those rural communities that are known for poor infrastructural basic amenities, low income generation and distribution, poor standard of living and unattractiveness to outside investors. 


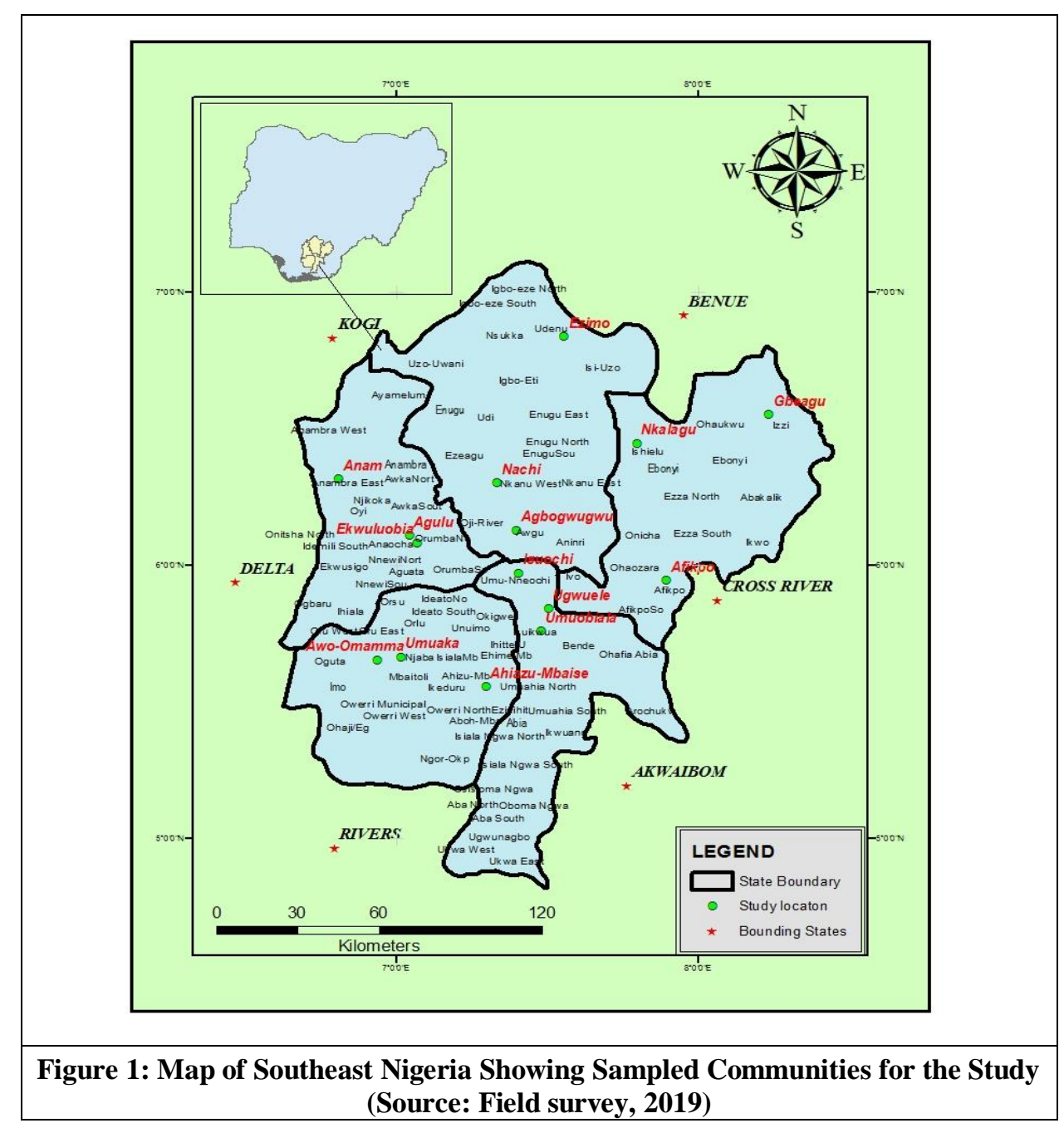

\section{LITERATURE REVIEW}

Some studies have it that rural communities are among the list developed areas in most developing countries and that such places require significant provision of basic amenities and improved standard of living to motivate residency at such areas (see Uzobo \& Dawodu 2015; Adedeji, Olafiaji, Omole, Olanibi and Yusuf, 2014; Udensi, et al 2012; Olayiwola \& Adeleye 2005; Paul et al 2014; Ocheni, Atakpa \& Nwankwo 2012; Petrovic et al 2017). Also, another group of studies are of the opinion that some relevant programmes and project initiatives should be designed and executed by both public and private sectors including NGO's to improve the infrastructural and economic base of the rural areas to curb the menace of ruralurban migration (Egbe 2014; Musa 2010; Nchuchuwe \& Adefila \& Yusuf 2014; Saliv 2014).

Moreover, rural tourism was also discussed extensively and suggested as among the solutions to the challenges of rural areas in many parts of the globe. Also, that rural tourism development if systematically managed does not only enhance the economic base of rural areas but also has the tendencies of promoting rural cultures and lifestyles, promoting common identity and harnessing the potentialities of rich heritage resources of the area. It further promotes personal comfort and pride in rural residency among rural adults (see Ivolga \& Erokhin 2013; Oruonye 2013; Okech, Haghiri \& George 2012; Jurowski, Uysal, \& Williams 1997; McGregor \& Thompson-Fawcett 2011; Moller 2016; Ibanescu et al 2018). 
Tourism involves movement and movement involves travel. Tourism circle is not completed without any kind of movement/travel. However, safety is part of major considerations in travel motivations and choices. For instance, Galaviz et al (2016), McGehee and Andereek, Cerin et al (2017) and Beck et al (2017) in their separate studies concluded that relative fears and other unknown factors from the physical environment and neighbourhood affect older adults perception and free movement outside their original homes. Some other studies from Europe and American informed that fear of road crashes leading to deaths and life threatening informs limit of the frequency of travels among adults (Zwerling et al, 2005; Dwyer-Lindgren et al, 2016; Travis et al 2012; Muellman et al, 2007). McAndrew et al (2016) and Li, Braver and Chen (2003) are of the view that such conditions and perceptions are high among older adults residing in rural communities. This is the case with adults residing in some developed parts of the globe like Europe and America.

In conclusion, this brief literature review has been able to identify the contributions of travel and tourism to the sustainable development of rural communities, and also the fear of accidents and other unknown life-threatening factors as among causes of limited frequency of travels and other tourism activities among older adults.

\section{RESULTS}

Research Question One: What is the perception of safety on travels among rural adults?

Table 1: Mean Analysis of the Ratings of the Respondents on the Perception of Safety on Travels among Rural Adults

\begin{tabular}{|c|l|c|c|l|}
\hline S/N & \multicolumn{1}{|c}{ Item Statement } & Mean & SD & Decision \\
\hline 1 & I have phobia for travels due to safety concerns & 3.19 & .90 & Agree \\
\hline 2 & $\begin{array}{l}\text { Inter and intra-state travels are safe in Southeast } \\
\text { Nigeria }\end{array}$ & 2.89 & 1.05 & Agree \\
\hline 3 & $\begin{array}{l}\text { Fear of armed robbery attacks deprive me from } \\
\text { embarking on travels }\end{array}$ & 3.44 & .76 & Agree \\
\hline 4 & $\begin{array}{l}\text { Fear of terrorists attack is the bane for smooth } \\
\text { travels for rural adults }\end{array}$ & 3.38 & .79 & Agree \\
\hline 5 & $\begin{array}{l}\text { Availability of good roads motivate smooth travels } \\
\text { in Southeast Nigeria }\end{array}$ & 3.22 & .80 & Agree \\
\hline 6 & $\begin{array}{l}\text { Travelling keeps your house vulnerable for robbers } \\
\text { and other criminals }\end{array}$ & 3.20 & 1.15 & Agree \\
\hline 7 & $\begin{array}{l}\text { Commercial vehicle drivers and other road users } \\
\text { drive recklessly }\end{array}$ & 2.99 & .98 & Agree \\
\hline 8 & $\begin{array}{l}\text { Most commercial vehicles are well maintained for } \\
\text { inter and intra-state travels }\end{array}$ & 2.77 & .92 & Agree \\
\hline 9 & $\begin{array}{l}\text { Tourist and leisure sites in the state are safe for } \\
\text { visits and enjoyments }\end{array}$ & 2.76 & .92 & Agree \\
\hline 10 & $\begin{array}{l}\text { I travel less because of fear of stomach poison and } \\
\text { other contagious disease. }\end{array}$ & 2.81 & 1.07 & Agree \\
\hline 11 & $\begin{array}{l}\text { Safety concerns deprive me of travelling to visit } \\
\text { friends and relatives within and outside the state }\end{array}$ & 3.36 & .84 & Agree \\
\hline 12 & $\begin{array}{l}\text { Inter-community crisis deprives me of travelling to } \\
\text { neighbouring communities }\end{array}$ & 3.44 & .64 & Agree \\
\hline 13 & $\begin{array}{l}\text { Activities of community vigilante motivate travels } \\
\text { in rural areas to neighbouring communities }\end{array}$ & 3.15 & .79 & Agree \\
\hline 14 & $\begin{array}{l}\text { Fear of kidnappers prevent inter and intra-state } \\
\text { travels }\end{array}$ & 3.04 & .68 & Agree \\
\hline 15 & $\begin{array}{l}\text { Travel exposes someone to unnecessary losses and } \\
\text { regrets }\end{array}$ & 2.69 & .85 & Agree \\
\hline & Overall Mean & 3.09 & .34 & Agree \\
\hline
\end{tabular}


The table shows that the mean ratings of the respondents on items 1 to 15 are more than the criterion mean of 2.50. This means that the respondents agreed to the statements of the items as the perception of safety on travels among rural adults.

Research Question Two: What are the implications of safety on travels for sustainable development of rural communities?

Table 2: Mean Analysis of the Ratings of the Respondents on the Implications of Safety on Travels for Sustainable Development of Rural Communities

\begin{tabular}{|c|c|c|c|c|}
\hline $\mathbf{S} / \mathbf{N}$ & Item Statement & Mean & SD & Decision \\
\hline 1 & $\begin{array}{l}\text { Travel by rural adults brings innovative ideas for } \\
\text { rural development }\end{array}$ & 2.79 & .89 & Agree \\
\hline 2 & $\begin{array}{l}\text { Intra-rural travels among rural adults promote } \\
\text { income generation in the rural communities. }\end{array}$ & 2.82 & .76 & Agree \\
\hline 3 & $\begin{array}{l}\text { Inter-rural travels among rural adults promote } \\
\text { income generation in the rural communities. }\end{array}$ & 2.64 & 1.07 & Agree \\
\hline 4 & $\begin{array}{l}\text { Travels among rural adults promote technical } \\
\text { know-how in the rural communities. }\end{array}$ & 3.29 & .89 & Agree \\
\hline 5 & $\begin{array}{l}\text { Travels among rural adults facilitate high adult } \\
\text { literacy level in the rural communities. }\end{array}$ & 3.17 & .79 & Agree \\
\hline 6 & $\begin{array}{l}\text { Travels among rural adults enhances agricultural } \\
\text { practices in the rural communities. }\end{array}$ & 3.24 & .77 & Agree \\
\hline 7 & $\begin{array}{l}\text { Travels by rural adults promote community health } \\
\text { in the rural communities. }\end{array}$ & 2.98 & .90 & Agree \\
\hline 8 & $\begin{array}{l}\text { Travels by rural adults bring about political } \\
\text { awareness in the rural communities. }\end{array}$ & 2.86 & .86 & Agree \\
\hline 9 & $\begin{array}{l}\text { Travels by rural adults enhance entrepreneurial } \\
\text { development in the rural communities. }\end{array}$ & 3.09 & .80 & Agree \\
\hline 10 & $\begin{array}{l}\text { Travel promotes enhanced religious life among } \\
\text { rural adults in rural communities. }\end{array}$ & 3.27 & .78 & Agree \\
\hline 11 & $\begin{array}{l}\text { Travels promote better social life for rural adults in } \\
\text { rural communities. }\end{array}$ & 3.15 & .80 & Agree \\
\hline 12 & $\begin{array}{l}\text { Travels promote better cultural life for rural adults } \\
\text { in rural communities. }\end{array}$ & 3.14 & .71 & Agree \\
\hline 13 & $\begin{array}{l}\text { Travels bring about positive modifications for } \\
\text { indigenous values and tradition }\end{array}$ & 2.92 & .89 & Agree \\
\hline 14 & $\begin{array}{l}\text { Travels by rural adults promote inter and intra- } \\
\text { rural relations among rural communities }\end{array}$ & 3.00 & .81 & Agree \\
\hline \multirow[t]{2}{*}{15} & $\begin{array}{l}\text { Travels among rural adults promote peace and } \\
\text { cohesion for productivity in rural communities }\end{array}$ & 3.04 & .83 & Agree \\
\hline & Overall Mean & 3.03 & .41 & Agree \\
\hline
\end{tabular}

Table 2 reveals that the mean ratings of the respondents on items 1 to15 which border on the implications of safety on travels for sustainable development of rural communities are more than the 2.50 criterion mean. Thus, statements of items 1 to 15 are the implications of safety on travels for sustainable development of rural communities.

Ho1: There is no significant difference in the mean ratings of TD experts, CD experts and rural adults on the perception of safety on travels among rural adults. 
Table 3: Analysis of Variance of the Difference in the Mean Ratings of TD Experts, CD Experts and Rural Adults on the Perception of Safety on Travels Among Rural Adults

\begin{tabular}{|l|c|c|c|c|c|c|}
\hline \multicolumn{1}{|c|}{ Group } & $\mathbf{n}$ & Mean & Std. Deviation & df & F & Sig \\
\hline Td experts & 58 & 3.17 & .31 & & & \\
\hline Cd experts & 59 & 3.06 & .35 & \multirow{2}{*}{1,351} & \multirow{2}{*}{1.907} & .150 \\
\hline Rural adults & 236 & 3.08 & .34 & & & \\
\hline \multicolumn{1}{|c|}{ Total } & $\mathbf{3 5 4}$ & $\mathbf{3 . 0 9}$ & $\mathbf{. 3 4}$ & & & \\
\hline
\end{tabular}

Table 3 shows that TD experts had the highest mean rating $(\mathrm{x}=3.17, \mathrm{SD}=.31)$, followed by the rural adults $(\mathrm{x}=$ $3.08, \mathrm{SD}=.34)$ while the $\mathrm{CD}$ experts had the least mean rating $(\mathrm{x}=3.06, \mathrm{SD}=.35)$. However, there is no significant difference in the mean ratings of $\mathrm{TD}$ experts, $\mathrm{CD}$ experts and rural adults on the perception of safety on travels among rural adults, $\mathrm{F}(1,351)=1.907, \mathrm{p}=0.150$.

Ho2: There is no significant difference in the mean ratings of TD experts, CD experts and rural adults on the implications of safety on travels for sustainable development of rural communities.

Table 4: Analysis of Variance of the Difference in the mean Ratings of TD Experts, CD Experts and Rural Adults on the Implications of Safety on Travels for Sustainable Development of Rural Communities

\begin{tabular}{|c|c|c|c|c|c|c|}
\hline Group & n & Mean & Std. Deviation & df & $\mathbf{F}$ & Sig \\
\hline Td experts & 58 & 3.05 & .46 & \multirow{4}{*}{1,351} & \multirow{4}{*}{1.432} & \multirow{4}{*}{.187} \\
\hline Cd experts & 59 & 3.07 & .40 & & & \\
\hline Rural adults & 236 & 3.00 & .40 & & & \\
\hline Total & 354 & 3.03 & .41 & & & \\
\hline
\end{tabular}

Table 4 shows that $\mathrm{CD}$ experts had the highest mean rating $(\mathrm{x}=3.07, \mathrm{SD}=.46)$, followed by the $\mathrm{TD}$ experts $(\mathrm{x}=$ $3.05, \mathrm{SD}=.46)$ while the rural adults had the least mean rating $(\mathrm{x}=3.00, \mathrm{SD}=.40)$. However, there is no significant difference in the mean ratings of TD experts, $\mathrm{CD}$ experts and rural adults on the implications of safety on travels for the sustainable development of rural communities, $F(1,351)=1.432, \mathrm{p}=0.187$.

\section{DISCUSSIONS}

This study attempted to address two critical questions with a view to understanding the influence of safety on travel decisions among rural adults in southeast Nigeria, and also how travel can motivate sustainable development of rural communities in Southeast Nigeria. Data from questionnaires, Key Informant Interviews, observations and relevant literature will be discussed simultaneously to address the objectives of the study.

First and foremost, the first research objective was to understand the influence of safety as a factor in travel decisions among rural adults in southeast Nigeria. In Table 1, the cumulative response from respondents shows that safety is a factor in travel decisions among rural adults in rural Nigeria. High safety threats which include kidnapping, robbery attacks, road accidents among others, were listed among safety concerns. Even when some of these rural adults would like to visit tourist sites within their states, there are many limitations to such decisions. This information was confirmed by some other rural adults who were sampled for Key Informant Interviews. Apart from $15 \%$ of them who affirmed that they enjoy travelling both within and outside their states of origin, (either to tourist sites, to see friends, or for some other interesting programs) the remaining percentage of the informants $(85 \%)$ noted the presence of safety concerns on-road travels in Nigeria. 
The issue of inter-community crisis is another safety concern that discourages rural adults from regular inter and intra-state travels in the study area. During the observation, this particular safety concern was not rampant as there were only a few places with crisis. Also, observation at some of these rural communities and nearby transport companies revealed that only a minute percentage of rural adults within the bracket of the study do patronize these transport companies. Those of them who have private cars prefer driving within their neighbourhood and sending younger people on errands outside the community.

A similar study in the United States (see Galgviz, et al 2016; Beck et al 2017; Cerin et al 2017) affirm that older adults from rural areas have many safety considerations when making travels outside their original residence. The nature of the result from these thoughtful considerations determines their travel and destination choices. Also, Jurowski et al (1997) and, McGehee and Andereck (2004) in their separate studies cited safety predictions among rural residents before making travel and/or destination choices. In Figure 2 below, Cerin et al (2017) were able to illustrate that safety threat is among the limiting factors against travels in adults. This is considered under appeal factors not minding the accessibility factors. Considering the results from the various sources of data for this study, one can conclude that there is a high safety perception for travels among rural adults when considering travel choices, travel modes and destination choices in rural communities in Nigeria and some other parts of the globe.

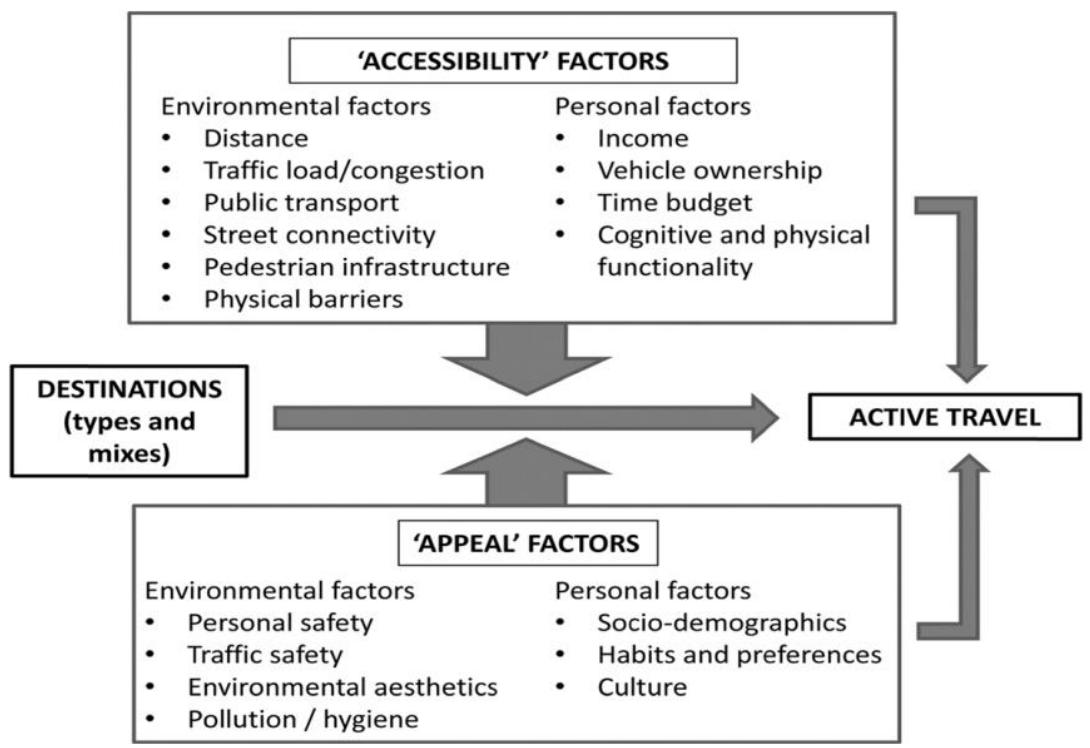

Figure 2: A Proposed Conceptual Framework of AAA+ Destinations: Available, Accessible, Appealing for Active Travel in an Ageing Population.

(Source: Cerin et al, 2017)

Moreover, the second objective of the study was to find out the implications of safety on travels for sustainable development of rural communities in Nigeria. In this regard, all the item statements in Table 2 were confirmed by the three categories of respondents as among the implications of safety on travels for sustainable development of rural communities. The implication of this result is that there is total agreement among respondents that travels outside rural communities, enhances sustainable development at rural areas through information, enlightenment, new ideologies, opportunities for comparative judgments on development strides, exposure to current trends and solutions to managing rural crisis and other socio-economic limitations, comparative consideration of indigenous values and cultural status, among others. These factors which are enhanced and motivated by travels have the capacity of transforming the socio-economic status of rural 
communities with a view to achieving sustainable development in the rural areas.

During interview sessions, some informants from Ebonyi and Abia states informed that sometimes the community leadership may decide to send some people to attend some enlightenment programs outside the community or to learn new economic opportunities that can transform their communities. Sometimes it could be handicrafts and other smallscale technologies that would be of importance to the communities. But unfortunately, safety concerns limit travels among these rural adults. In support of this, similar studies from some other parts of the world, note that travels and other positive expositions have the tendencies of transforming the fortunes of rural communities which have been described as a place for the poor due to limited or poor economic opportunities and other social variables (see Ivolga \& Erokhin, 2013; Moller, 2016; Ibanescu, 2018; Okech et al, 2012). Also, in a similar study Petrovic et al (2017) inform that travel and tourism have the potentialities of transforming the fortunes of rural communities in Serbia and Slovenia through the introduction of transformational ideas and new trends.

Also, selected community development experts and tourism development experts for the study supported this argument by affirming that travels of all kinds among rural adults bring exposure to these rural communities which can translate to the sustainable development of rural communities. However, it can be deduced that travels have positive implications for the sustainable development of rural communities, though its capacities in this rural transformation can be hindered by safety concerns on travel decisions among rural adults.

\section{CONCLUSIONS}

This study was aimed at understanding the perception of safety with respect to travel among rural adults, and also the implications of safety on travel for sustainable development of rural communities in Nigeria but with more emphasis on Southeast Nigeria. The result of the study revealed that rural adults have many safety considerations for travels hence the frequency of their travels outside their communities is minimal. There is a high perception of safety considerations among rural adults in Nigeria. This outcome was equally supported by some other related studies from other parts of the globe (see Kostynivk et al 2012; Adedeji et al 2014; Hasan et al 2017).

Moreover, from the second research question, it was discovered that travels outside rural communities among rural adults have huge implications for sustainable development in rural areas. Travels expose rural adults to new information, current trends, new ideologies and strategies, comparative considerations with some other communities on related issues, among others. That is to say, that travel as a concept has a role to play in solving the current poor standard of living and economic base of the rural communities in Nigeria. Limited facilities and infrastructural base, inequitable job distribution and unemployment, constant depopulation and rural-urban migration are among the challenges of most rural areas in Nigeria.

Despite this, safety concerns have posed strict limitations to the harnessing of the potentialities of travel in sustainable community development. What then can be done? There is a need for a massive orientation of rural adults on travels and its importance in rural development. Efforts should be made by relevant authorities on how best to manage those safety issues that limit travel among rural adults. Leadership of rural communities may need to form the habit of sending some adults on fact-finding missions to neighbouring communities to interact and discuss current approaches to rural developments. The development of many tourism resources in rural communities in Nigeria will motivate travel and tourism experiences among rural adults. This can be achieved through various government tourism agencies like the 
Nigerian Tourism Development Commission (NTDC), State Tourism Boards (STD's), and Local Government Tourism Committees (LGTC's).

In conclusion, it is expected that future studies would further this cause by investigating various measures of controlling travel-associated safety issues as perceived by rural adults. This will not only restore the trust of these rural adults on travel but also boost travels of all kinds among rural adults in Nigeria. This will have great positive implications for the sustainable development of rural communities in Nigeria.

\section{ACKNOWLEDGEMENTS}

The authors wish to appreciate all the study participants for their active participation in the research. Also, appreciated is Dr. Elochukwu A. Nwankwo of the Department of Archaeology and Tourism, University of Nigeria, Nsukka (elochukwu.nwankwo@unn.edu.ng) for serving as the corresponding author for the research.

\section{REFERENCES}

1. Adedeji, O.A., Olafiaji, E.M; Omole, F.K., Olanibi, J.A. and Yusuff, L. (2014). "An assessment of the impact of road transport on rural development: A case study of Obokun L.G.A of Osun State, Nigeria”. British Journal of Environmental Sciences 2(1), $34-48$.

2. Agboeze, M.U. and Nwankwo, E.A. (2016). “Appraising the implementation of Millennium Development Goal 1 projects at communities for sustainable development in Enugu State, Nigeria”. International Journal of Sustainable Society 8(4), 318337.

3. Sunita Meena, "Self Portrayal Through Travel Narratives", IMPACT: International Journal of Research in Humanities, Arts and Literature (IMPACT: IJRHAL) ISSN, Vol. 6, Issue 1, pp, 181-188

4. Beck, L.F., Downs, J., Stevens, M.R. and Sauber-Schatz, E.K. (2017). "Rural and urban differences in passenger-vehicleoccupant Deatus and Seat Belt use among adults". Morbidity and Mortality Weekend Report 66(17), 1-13.

5. Veeraj G. Mahatme, “Travel Motivations: Evaluating A Measurment Scale”, IMPACT: International Journal of Research in Humanities, Arts and Literature (IMPACT: IJRHAL), Vol. 6, Issue 9, pp, 41-50

6. Cerin, E., Nathan, A. Van Cauwenberg J., Barnett, D.W. and Barnett, A. (2017). "The neighbourhood physical environment and active travel in older adults: A systematic review and meta-analysis". International Journal of Behavioural Nutrition and Physical Activity 14(15), 1-23.

7. Chin, C.H.; Lo, M.C.; Songan, P.; Nair, V. (2014). "Rural Tourism Destination Competitiveness: A Study on Annah Rais Longhouse Homestay, Sarawak”. Procedia Soc. Behav. Sci. 144, 35-44.

8. Celia E. Carino, “Tourist Perception Towards Travel Risk in the Philippines: Basis for Travel Security and Safety Measures”, International Journal of Business Management \& Research (IJBMR), Vol. 7, Issue 2, pp, 49-58

9. Dolnicar, S. (2005). Understanding barriers to leisure travel: Tourist fears as a marketing basis. Journal of Vacation Marketing 11(3), 197-208.

10. Dwyer-Lindgren, L., Berrozzi-Villa, A. and Stubbs, R.W. (2016). "U.S. Country-level trends in mortality rates for major causes of deaths 1980-2014”. JAMA 316, 2385-2401.

11. Nouria Fleah Al-Juboori, Mohammed Jassim Al Sumaidaee \& Abdulsada Mutlag Al-Saleem, "The Impact of the Content of Electronic Communication Means on the Attitudes of Customers to Accept Dealing with the Tourism Products of Travel Agencies", International Journal of Business Management \& Research (IJBMR), Vol. 6, Issue 2, pp, 31-44 
12. Dzurec, L.C. and Abraham, I.L. (1993). "The nature of Enquiry: Linking quantitative and qualitative research". Advances in Nursing Science 16, 73-79.

13. Egbe, E.J. (2014). "Rural and community development in Nigeria: An assessment". Arabian Journal of Business and Management Review (Nigerian Chapter) 2(2), 17-30.

14. Galaviz, K.L., Zytnick, D., Kegler, M.C., and Cunningham, S.A. (2016). "Parental perception of neighborhood safety and children's physical activity”. Journal of Physical Activity and Health 13, 1110-1116.

15. Hall, R.D. (1998). “Tourism Development and Sustainability Issues in Central and South-Eastern Europe”. Tourism Management, 19, 423-431.

16. Hasan, K., Ishamail, A.R. and Islam, F. (2017). "Tourist risk perceptions and revisit intentions: A critical review of Literature”. Cogent Business \& Management 4, 1412874

17. Ibanescu, B.C., Stoleriu, O.M., Munteanu, A. and Latu, C. (2018). "The impact of tourism on sustainable development in Rural Areas: Evidence from Romania”. Sustainability 10 (3529), 1-19.

18. Ivolga, A. and Erokhin, V. (2013). "Tourism as an approach to sustainable Rural Development: Case of Southern Russia". Economics of Agriculture 60(4), 789-800.

19. Jones, S., Tedla, E.G., Zephniah, S.O. Appiah-Opoku, S., Tefe, M.K. and Walsh, J. (2014). Rural transport health and safety in sub-Saharan Africa. USA: AFCAP and CROWN AGENTS.

20. Koscak, M. (1998). “Integral Development of Rural Areas, Tourism and Village Renovation, Trebnje, Slovenia”. Tourism Management 19, 81-85.

21. Kostynivk, L.P., Louis, R.M., Zanier, N., Eby, D.W. and Molnar, L.J. (2012) Transportation, mobility, and older adults in rural Michigan. Michigan: Michigan Department of Transportation.

22. LGA \& PHE (2017). Health and wellbeing in rural areas England: A joint publication by local government association and public health England.

23. Li, G., Braver, E.R., and Chen, I.H. (2003). "Fragility versus excessive crash involvement as determinants of high death rates per vehicle-mile of travel among older Drives". Accident Analysis and Prevention 35, 227-235.

24. McAndrews, C. Beyer K., Guse, C.E., and Layde, P. (2016). "How do the definitions of urban and rural matter for transportation safety? Reinterpreting transportation fatalities as an outcome of regional development processes". Accident Analysis and Prevention 97, 231-214.

25. McGehee, N.G. and Andereck, K.L. (2004). "Factors predicting rural residents' support of tourism”. Journal of Travel Research 43, 131-140.

26. McGregor, S. and Thompson-Fawcett, M. (2011). "Tourism in a small town: Impacts on community solidarity”. International of sustainable society 3 (2), 174-189.

27. Moller, P. (2016). “Young adults' perceptions of and effective bonds to a rural tourism community”. Fennia 194 (1), $32-45$.

28. Muelleman, R.I., Wadman, M.C., Tran, T.P. Ullrich, F. and Anderson, J.R. (2007). "Rural motor-vehicle crash risk of death is higher after controlling for injury severity”. Journal of Trauma 62, 221-225.

29. Musa, J.J. (2010). "Nigeria's rural development strategy: Community driven development approach". AU J.T. 13 (4), 233 241 . 
30. Nduchuwe, F.F. and Adejuwon, K.D. (2012). "The challenges of agriculture and rural development in Africa: The case of Nigeria”. International Journal of Academic Research in Progressive Education and Development. 1(3), 45-61.

31. Ocheni, S., Atakpa, M. and Nwankwo, B.C. (2012). "Local government and appropriate capacity building for accelerated and sustainable rural development". European Journal of Business and Social Sciences 1(3), 131-135.

32. Okech, R., Haghiri, M., and George, B.P. (2012). "Rural tourism as a sustainable development alternative: An Analysis with special reference to Luanda, Kenya”. Culture 6(3), 36-54.

33. Olayiwola, L.M. and Adeleye, O.A. (2005). "Rural Infrastructural Development in Nigeria: Between 1960-1990 - Problems and Challenges". Journal of Social Sciences 11(2), 91-96.

34. Ononogbo, K.U. (2014). Assessment of residents' attitudes towards recreation in Bida-Nigeria. An unpublished research project, Ahmadu Bello University, Zaria.

35. Oruonye, E.D. (2013). "The challenges of rural tourism development in Nigeria: A case of Yorro Iga, Taraba State Nigeria". International Journal of Social Sciences, Arts and Humanities 1(1), 1-6.

36. Petrovic, M.D., Vujko, A., Gajic, T. Vukovic, D.B., Radovanovic, M., Jovanovic, J.M., and Vukovic, N. (2018). "Tourism as an approach to sustainable rural development in post-socialist countries: A comparative study of Serbia and Slovenia". Sustainability 10 (54), 1-14.

37. Reisinger, Y. and Mavondo, F. (2005). Cultural differences in travel risk perception. Journal of Travel and Tourism Marketing 20(1), 13-31.

38. Saliu, S.I. (2014). Evaluation of self help community development projects in Zungeru in Niger State, Nigeria. Greener Journal of Social Sciences 4(3), 093-107.

39. Todorovi'c, M.; Bjeljac, Ž. (2009). "Rural Tourism in Serbia as a Concept of Development in Undeveloped Regions”. Acta Geogr. Slov. 49, 453-473

40. Travis, L.L., Clark, D.E., Haskins, A.E., and Kilch, J.A. (2012). "Mortality in rural locations after severe injuries from motor vehicle crashes". Journal of Safety Research 43, 375-380.

41. Udensi, L.O., Udoh, O.S., Daasi, G.L.K., and Igbara F.N. (2012). "Community leadership and the challenges of community development in Nigeria: The case of Boki Local government area, Cross River State”. International Journal of Development and sustainability 1(3), 912-923.

42. Uzobo, E. and Dawodu, O.A. (2015). "Ageing and Health: A comparative study of rural and urban aged health status in Bayelsa State, Nigeria”. European Scientific Journal 11 (4), 258-273.

43. Vujko, A.; Petrovi'c, M.D.; Dragosavac, M.; Gaji'c, T. (2016). "Differences and Similarities among Rural Tourism in Slovenia and Serbia-Perceptions of Local Tourism Workers”. Ekon. Poljopr. Econ. Agric 63, 1459-1469

44. Wang, P. (2013). The influence of tourists'safety perception. Switzerland: Springer International Publishing.

45. Woosnam, K.M. (2012). "Using Emotional Solidarity to explain residents' attitudes about tourism and tourism Development". Journal of Travel Research 51, 315-327

46. Zwerling, C., Peek-Asa, C., Whitten, P.S. Choi, S.W., Sprince N.L. and Jones, M.P. (2005). "Fatal motor vehicle crashes in rural and urban areas: Decomposing rates into contributing factors". International Journal of Prevention 11, 24-28. 